Oleksandr Pokutsa', Andriy Zaborovskiy', Daria Maksym', Roman Makitra', Jacques Muzart ${ }^{2}$ and Andrzej Sobkowiak ${ }^{3}$

\title{
THE INFLUENCE OF THE REACTION MEDIUM ON THE CLEAVAGE OF HYDROGEN PEROXIDE CATALYZED WITH COBALT IONS
}

\author{
${ }^{1}$ Department of Physical Chemistry of Combustible Fossils NAS of Ukraine \\ 3A Naukova str., 79053 Lviv, Ukraine, Pocutsa@org.lviv.net \\ ${ }^{2}$ Unite Mixte de Recherche. "Reactions Selectives et Applications" CNRS-Universite de Reims \\ Champagne-Ardenne BP 1039, 51687 Reims Cedex 2, France \\ ${ }^{3}$ Rzeszow University of Technology, P.O. Box 85, 35-959 Rzeszow, Poland
}

Received: January 10, 2008

\begin{abstract}
Using the method of inhibitors the peculiarities of $\mathrm{H}_{2} \mathrm{O}_{2}$ cleavage catalyzed by cobalt (II)acetylacetonate in different hydrophilic solvents was studied. As was established, physical-chemical properties of the reaction medium can significantly affect the rate of peroxide decomposition and catalyst oxidation.
\end{abstract}

Key words: catalytic cleavage, hydrogen peroxide, cobalt (II) ions, solvents, inhibitor.

\section{Introduction}

A solvent can affect the kinetics of the homogeneous oxidation processes by influencing their elementary steps $[1,2]$. As a rule, the range of these changes does not exceed one order of magnitude (usually 200-300\%). In spite of relatively low sensitivity of such processes towards the nature of a solvent, accelerating the velocity of certain elemental steps can notably influence the target products yield. An initiation stage is one of the elementary stages which are most sensitive to the reaction medium. Thus studying the role of this stage in the general mechanism of oxidation is of great importance.

Commonly, decomposition of peroxide-like compounds is responsible for the initiation. Due to the generally accepted opinions the decomposition of peroxides occurs along the two parallel routes - heterolytic (non-radical) and induced (radical) [3]. The role of the solvent in this type of reactions is conditioned by its solvating properties [4], which particularly affect the heterolytic decomposition. At the same time the induced moiety is mainly dependent on the solvent's self-association value (density of cohesion energy) [5]. The increase of the last member accelerates the rate supposedly by enforcing the "cage" effect in the "solventsolvent" and "solvent-peroxide" system [6]. The last effect causes decreasing of the reaction barrier and increases the rate of the induced moiety of the cleavage [7].
This work continues the study of the peculiarities of the peroxides catalytic cleavage in organic solvents that has been started in [8]. The selection of $\mathrm{H}_{2} \mathrm{O}_{2}$ as an object of investigation is due to its unique qualities (ecological safety, technological versatility and economical attractiveness), that allow applying it as a relevant oxidant for numerous organic substrates oxifunctionalization. The kinetics results have been obtained by using the method of inhibitors as one of the most proven, informative and accepted tools for radical reactions studying.

\section{Experimental}

The kinetics of $\mathrm{H}_{2} \mathrm{O}_{2}$ consumption has been studied at $308 \mathrm{~K}$ in a thermostatted $25 \mathrm{ml}$ glass cell. The reaction mixture (total volume $20 \mathrm{ml}$ ) was stirred with a Teflon covered magnetic stirring bar. In the beginning (prior to adding $\mathrm{H}_{2} \mathrm{O}_{2}$ ) nitrogen was being bubbled through the reaction mixture for 5-10 min. Following that a determinate volume of peroxide was injected into the deaerated mixture by a syringe and this moment was taken as the start of the reaction. The content of $\mathrm{H}_{2} \mathrm{O}_{2}$ in the reaction medium during the experiment was being monitored by the titration of the probes withdrawn from the reaction mixture with defined intervals. $0.01 \mathrm{~N}$ water solution of $\mathrm{Na}_{2} \mathrm{~S}_{2} \mathrm{O}_{3}$ was used as a titrant. The probe $(1 \mathrm{ml})$ withdrawn with a pipette was poured into $250 \mathrm{ml}$ conical flask that initially contained $2 \mathrm{ml}$ of $\mathrm{H}_{2} \mathrm{SO}_{4}(4 \mathrm{~N} \mathrm{aq}$ solution) and $2 \mathrm{ml}$ of $\mathrm{KI}$ (saturated $a q$ solution) in $100 \mathrm{ml}$ of distilled water. The resulted brown mixture was being preserved in a dark place for $30 \mathrm{~min}$ and then titrated with sodium tiosulphate under vigorous stirring till light-yellow color was obtained. Following that 2-3 drops of $10 \% a q$ solution of starch was added and the flask content was titrated colorless. Before each experiment the "blank" titration (without a probe) was conducted in order to abate the influence of dissolved oxygen on the results of the analysis. Usually, the error of 
measurement caused by the presence of dissolved $\mathrm{O}_{2}$ was $<1 \%$ from the total (including $\mathrm{H}_{2} \mathrm{O}_{2}$ ) consumption of titrating agent.

In order to avoid probable exceeding consumption of hydrogen peroxide in the reaction with the solvents capable of oxidizing in the experimental conditions (morpholine) "blank" titrations (in the absence of $\mathrm{Co}^{2+}$ ) of $\mathrm{H}_{2} \mathrm{O}_{2}$ solution in such solvents have been carried out. The obtained results were taken into account for calculation of the rate of hydrogen peroxide decomposition catalyzed by cobalt ions.

The electronic absorption spectra of the investigated solutions were recorded using Hewlett Packard 8453 and SF-20 spectrophotometers (1 cm quartz cuvettes).

Quinone ( $\mathrm{InH}$ ) was synthesized from hydroquinone by the method described in [9] and purified by double recrystallization from ethanol.

The solvents (for the analysis) were purified by conventional methods [10] and distilled before each series of experiments.

Cobalt (II)acetylacetonate $\left(\mathrm{Co}(\mathrm{acac})_{2}\right)(99 \%$ grade, Aldrich) was used as purchased.

The contribution of the non-radical (heterolytic) moiety of the rate of hydrogen peroxide cleavage can be calculated using the following equation:

$$
W=W_{\text {ind }}+W_{\text {het }}
$$

where: $W$-total rate of $\mathrm{H}_{2} \mathrm{O}_{2}$ cleavage, $\mathrm{M} \cdot \mathrm{s}^{-1} ; W_{\text {ind }}-$ induced (radical) moiety of total rate of cleavage, $\mathrm{M} \cdot \mathrm{s}^{-1}$;
$W_{\text {het }}$ - non-radical (heterolytic) component of total rate of $\mathrm{H}_{2} \mathrm{O}_{2}$ cleavage in the presence of free-radical inhibitor (quinone), $\mathrm{M} \cdot \mathrm{s}^{-1}$.

\section{Results and Discussion}

The experimental rates of pseudo-first order of $\mathrm{H}_{2} \mathrm{O}_{2}$ cleavage catalyzed with $\mathrm{Co}^{2+}$ indicate the significant influence of solvents on the process under consideration (Fig. 1, Table 1).

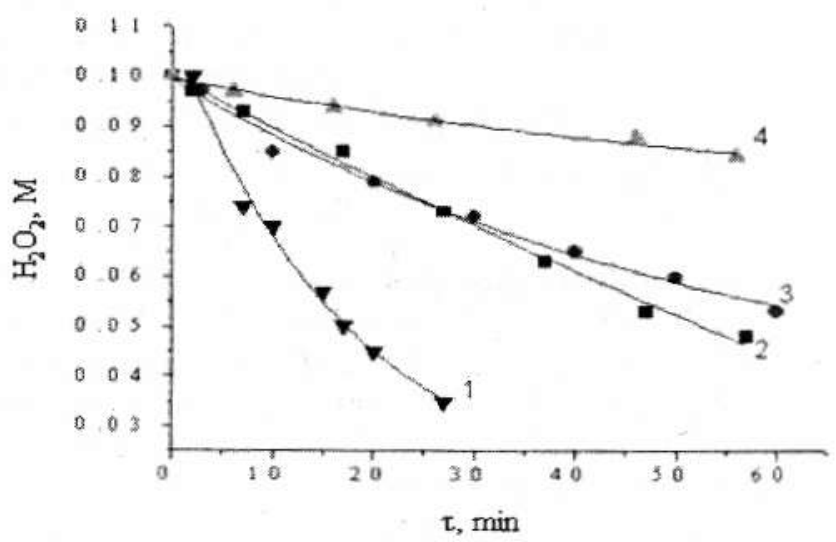

Fig. 1. Kinetics of $\mathrm{Co}^{2+}$ catalyzed cleavage of $\mathrm{H}_{2} \mathrm{O}_{2}$ in THF (1), $\mathrm{MeCN}$ (2), $\mathrm{AcOH}(3)$, and morpholine (4) at $308 \mathrm{~K}$

Table 1

Total rate of hydrogen peroxide consumption $(W)$ and it heterolytic $\left(W_{\text {hee }}\right)$ and induced $\left(W_{\text {ind }}\right)$ moieties

\begin{tabular}{|c|c|c|c|c|}
\hline Solvent & $\mathrm{W} \cdot 10^{5}, \mathrm{M} \mathrm{s}^{-1}$ & $\mathrm{~W}_{\text {het }} \cdot 10^{5}, \mathrm{M} \cdot \mathrm{s}^{-1}$ & $\mathrm{~W}_{\text {ind }} \cdot 10^{5}, \mathrm{M} \cdot \mathrm{s}^{-1}$ & $\mathrm{~W}_{\text {ind }} / \mathrm{W}, \%$ \\
\hline$i$-PrOH & 19.0 & 2.5 & 16.5 & 87 \\
\hline$t$ - BuOH & 18.0 & 2.1 & 15.9 & 88 \\
\hline $\mathrm{HOAc}$ & 6.2 & 0.8 & 5.4 & 71 \\
\hline $\mathrm{H}_{2} \mathrm{O}$ & 1.4 & 0.4 & 1.0 & 42 \\
\hline Dioxane & 1.2 & 0.7 & 0.5 & 57 \\
\hline Morpholine & 1.4 & 0.6 & 0.8 & 75 \\
\hline McCN & 5.5 & 0.8 & 4.7 & 81 \\
\hline THF & 18.0 & 3.5 & 14.5 & \\
\hline
\end{tabular}

Note: $\left[\mathrm{H}_{2} \mathrm{O}_{2}\right]_{0}=100 \mathrm{mM} ;\left[\mathrm{Co}^{2+}\right]_{0}=5 \mathrm{mM} ;[\text { Quinone }]_{0}=10 \mathrm{mM}$; the temperature is $308 \mathrm{~K}$

In the solvents containing hydroxyl groups 2-propanol $(i-\mathrm{PrOH})$ and 2-methyl-2-propanol $(t-\mathrm{BuOH})$ the cleavage rate is so high $\left(W \approx 2 \cdot 10^{-3} \mathrm{M} \cdot \mathrm{s}^{-1}\right)$ that after approximately $20 \mathrm{~min}$ from the insertion of peroxide into the reaction mixture the concentration of the last one verged towards zero. At the same time in water and acetic acid $(\mathrm{AcOH})$ the cleavage of $\mathrm{H}_{2} \mathrm{O}_{2}$ is notably slower. The reaction under consideration runs even slower in electrondonating dioxane and particularly in morpholine. The discovered experimental fact correlates with the dependence of the rate of peroxide cleavage upon specific (ability to form donor-acceptor complexes) and nonspecific (electrostatic) solvation of $\mathrm{H}_{2} \mathrm{O}_{2}$ by the molecules of the solvent [11]. Hence the solvents with hydroxyl groups (alcohols) and, to a bit less degree acids and water facilitate the cleavage of peroxide. At the same time electrondonating solvents (morpholine and dioxane) stabilize it.

The presence of the inhibitor (quinone) significantly changes the picture observed for the non-inhibiting process (Fig. 2, Table 1). It is known that in free-radical processes free-valent species are able to induce decomposition of the compounds with the weakened $\mathrm{O}-\mathrm{O}$ bonds. The free- 
radicals inhibitors slow this route [12] enabling the quantitative estimation of each route's input (heterolytic and induced) in the total rate of peroxide consumption.

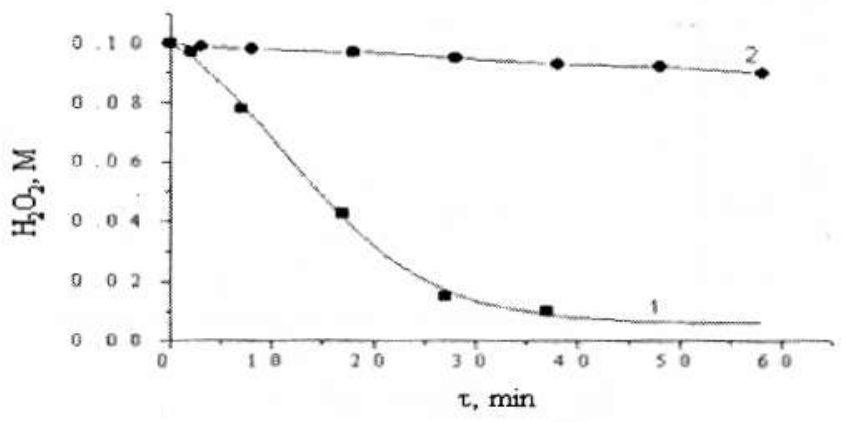

Fig. 2. Kinetics of catalyzed with $\mathrm{Co}^{2+}$ cleavage of $\mathrm{H}_{2} \mathrm{O}_{2}$ in $i-\mathrm{PrOH}$ without $\mathrm{InH}(1)$ and in the presence of $20 \mathrm{mM}$ of quinone (2) at $308 \mathrm{~K}$

As was determined experimentally (Fig. 3) exceeding quinone concentration over $10 \mathrm{mM}$ has practically no influence on the rate of $\mathrm{H}_{2} \mathrm{O}_{2}$ cleavage any more. At the same time such content of InH in the reaction mixture $\left(10-20 \%\right.$ from the initial concentration of $\left.\mathrm{H}_{2} \mathrm{O}_{2}\right)$ can not noticeably influence the titrating agent $\left(\mathrm{Na}_{2} \mathrm{~S}_{2} \mathrm{O}_{3}\right)$ consumption and radical component of hydrogen peroxide decomposition rate. (Quinones, by analogy with alkylphenols [12] can be oxidized with free-radical products of $\mathrm{H}_{2} \mathrm{O}_{2}$ cleavage with the formation of their peroxide-like derivatives). Hence it can be assumed that at such concentration of $\mathrm{InH}$ cleavage of peroxide in the tested solvents occurs mainly along the non-radical route. This enables experimental determination of heterolytic moiety of $\mathrm{H}_{2} \mathrm{O}_{2}$ decomposition.

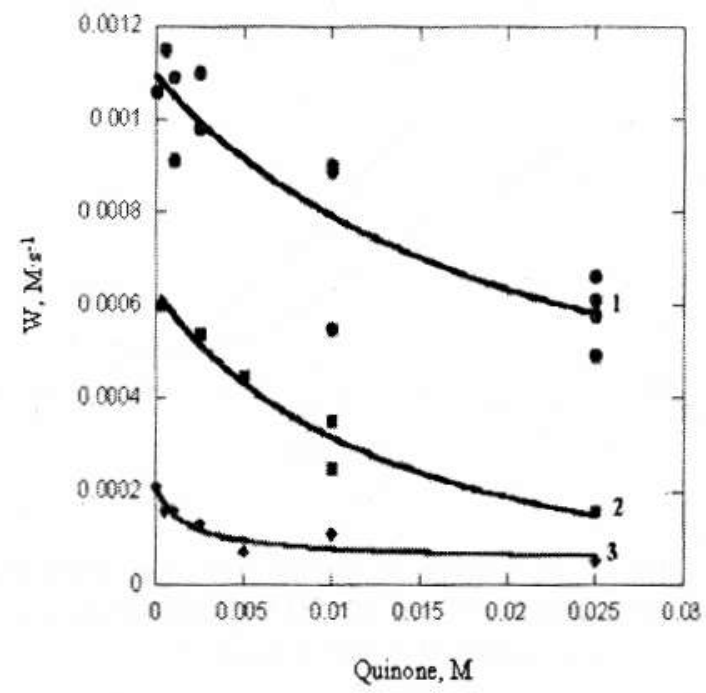

Fig. 3. Rates of $\mathrm{H}_{2} \mathrm{O}_{2}$ decomposition catalyzed by $10 \mathrm{mM}$ (1), $5 \mathrm{mM}$ (2) and $2.5 \mathrm{mM}$ (3) $\mathrm{Co}^{2+}$ depending on quinone concentration. $\left[\mathrm{H}_{2} \mathrm{O}_{2}\right]_{0}=50 \mathrm{mM}, \mathrm{T}=308 \mathrm{~K}, \mathrm{AcOH}$ medium
$\mathrm{H}_{2} \mathrm{O}_{2}$ decomposition rate in the solvents which are prone to self-association is more sensitive to the presence of quinone as compared to those containing no hydroxyl groups (Table 1). For example in alcohols and acetic acid the induced moiety of decomposition is about $90 \%$, followed by acetonitrile $(\mathrm{MeCN})$ and tetrahydrofurane (THF) (the reviewed value is equal $\approx 80 \%$ ), and then water, morpholine and dioxane (40-70\%). The aloof position of water in this range apparently is explained by the concerted influence of several electrochemical properties characteristic of $\mathrm{H}_{2} \mathrm{O}$. Their combination can be responsible for different behavior of this solvent as compared to alcohols and acids.

As follows from Table 1 the maximal ratio of bruttorates of $\mathrm{H}_{2} \mathrm{O}_{2}$ decomposition in the selected solvents is about $16\left(W_{\text {i-PoH }} / W_{\text {Diosane }}\right)$. For heterolytic decomposition this value is $9\left(W_{\text {THF }} / W_{\text {Water }}\right)$ and in case of the induced one $33\left(W_{\text {i-ProH }} / W_{\text {Dioxane }}\right)$. Thus in the testing conditions the reaction medium stronger affects the induced moiety of peroxide cleavage notably $(\approx 4$ times) than the non-radical one.

For additional clarification of the role of the solvent's nature in $\mathrm{Co}^{2+}$ ions transformation the electronic spectra of these ions in the selected solvents have been recorded before and after $\mathrm{H}_{2} \mathrm{O}_{2}$ treatment. The absorption maximums attributed to $\mathrm{Co}^{2+}$ and $\mathrm{Co}^{3+}$ (Table 2 ) as well as the velocity of these cations transformation after peroxide addition depended on physical-chemical properties of the solvent. According to the obtained data (Fig. 4, Table 2) in the solvents that are able to form strong intermolecular hydrogen bonds (alcohols) maximum absorption is observed at 490 and $605 \mathrm{~nm}$. The rate of $\mathrm{Co}^{2+}$ to $\mathrm{Co}^{3+}$ transformation after $\mathrm{H}_{2} \mathrm{O}_{2}$ addition in such solvents as well as in $\mathrm{MeCN}$ is diffusion-controlled. Interestingly, in $\mathrm{AcOH}$ and water, which by analogy with alcohols, are capable of creating associates, $[7,13]$ the batochromic shift of $\mathrm{Co}^{2+}$ ions absorption was observed (Table 2).

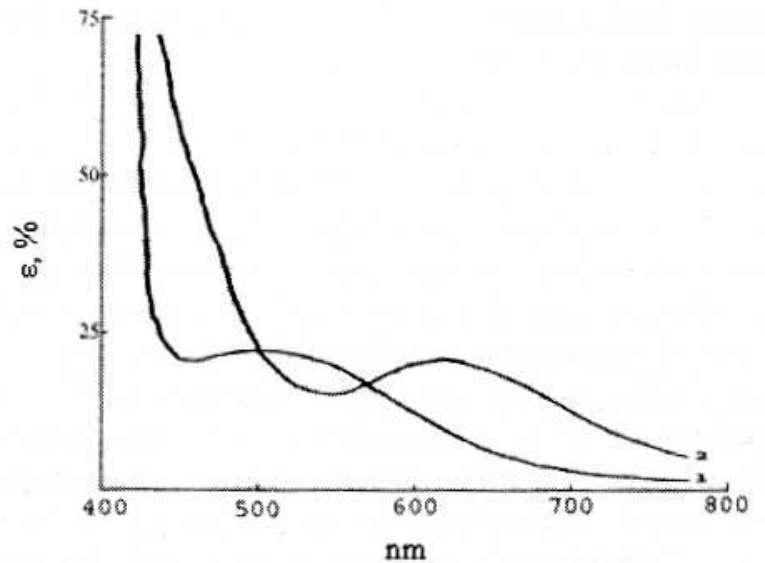

Fig. 4. Electronic absorption spectra of $1 \mathrm{mM} \mathrm{Co}{ }^{2+}$ in $i-\mathrm{PrOH}$

(1) and in the presence of $50 \mathrm{mM} \mathrm{H}_{2} \mathrm{O}_{2}(2)$ at $293 \mathrm{~K}$ 
Table 2

Maximums of absorption (nm) of $\mathrm{Co}^{2+}$ and $\mathrm{Co}^{3+}$ ions in the tested solvents at $293 \mathrm{~K}$

\begin{tabular}{|c|c|c|c|c|c|c|c|}
\hline $\begin{array}{c}\lambda_{\text {ation, }} \\
\mathrm{nm}\end{array}$ & $i-\mathrm{PrOH}$ & $\mathrm{HOAc}$ & $\mathrm{H}_{2} \mathrm{O}$ & Dioxane & Morpholine & $\mathrm{McCN}$ & $\mathrm{THF}$ \\
\hline$\lambda_{\mathrm{Co}_{0}^{2+}}{ }^{2+}$ & 490 & 545 & 530 & 520 & 550 & 510 & 525 \\
\hline$\lambda_{\mathrm{Co}_{0}}$ & 605 & 610 & 610 & 610 & 570 & 610 & 610 \\
\hline
\end{tabular}

In electron-donating solvents - morpholine, dioxane, and acetonitrile (Fig. 5) changes in $\mathrm{Co}^{2+}$ absorption spectrum occurred almost instantly (in 10-20 s) after $\mathrm{H}_{2} \mathrm{O}_{2}$ addition. However there are some inconsistencies between the rates of $\mathrm{Co}^{3+}$ formation and peroxide decomposition, which are still hard to explicate.

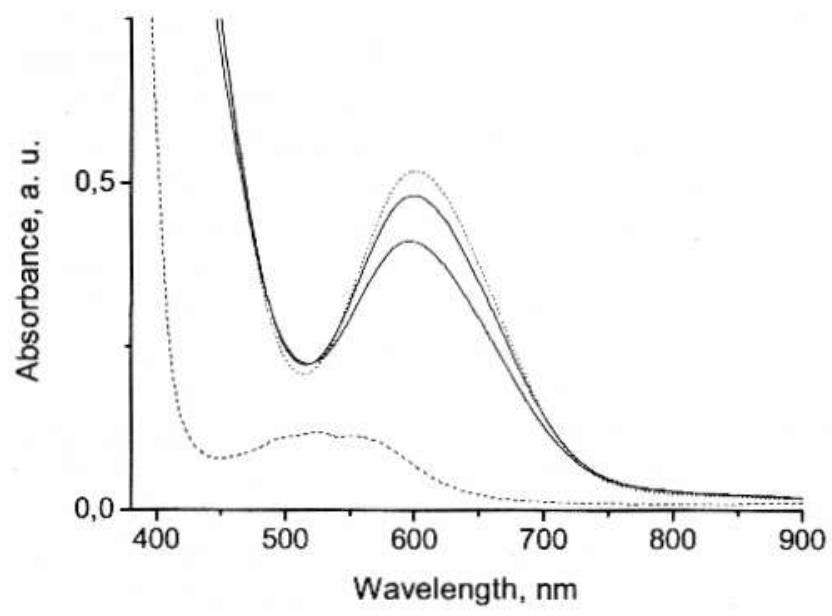

Fig. 5. Time-depending changes of UV-vis spectra of $5 \mathrm{mM}$ solution $\mathrm{Co}(\mathrm{acac})_{2}$ in $2 \mathrm{ml} \mathrm{MeCN}$ in the presence of $\mathrm{H}_{2} \mathrm{O}_{2}$ at $293 \mathrm{~K}$. The dash lines depict the initial spectrum of $\mathrm{Co}(\mathrm{acac})_{2}$, the dot line - the last spectrum taken after

$$
2 \mu \mathrm{l} \mathrm{H}_{2} \mathrm{O}_{2} \text { injection }
$$

Eventually it is explained by the fact that $\mathrm{Co}^{2+}$ oxidation in such solvents is mainly by ${ }^{\circ} \mathrm{OH}$-radicals. Unlike in the mentioned solvents the electronic spectrum of $\mathrm{Co}^{2+}$ in acetic acid solution remained unchanged for at least several hours after $\mathrm{H}_{2} \mathrm{O}_{2}$ addition (Fig. 6).

Absorption maximum of $\mathrm{Co}^{2+}$ in morpholine $(550 \mathrm{~nm})$, tetrahydrofurane $(525 \mathrm{~nm})$, dioxane $(520 \mathrm{~nm})$, and acetonitrile $(510 \mathrm{~nm}$ ) are shifted to batochromic (as compared to alcohols) region (Table 2). The wavelengths at which the absorption maximum is observed for $\mathrm{Co}^{3+}$ in $\mathrm{THF}$, dioxane, and $\mathrm{MeCN}(610 \mathrm{~nm})$ also coincide with the ones in the solvents capable of forming the hydrogen bonds (Table 2). The absorption maximum of $\mathrm{Co}^{3+}$ in morpholine $(570 \mathrm{~nm})$ is situated close to the characteristic peak of $\mathrm{Co}^{2+}$ in this solvent. Such a noticeable hypsochromic shift (which has been observed for more polar $\mathrm{Co}^{3+}$ ions) is explained by stronger electron-donating properties of morpholine and its lower polarity as compared to $\mathrm{MeCN}[14]$.

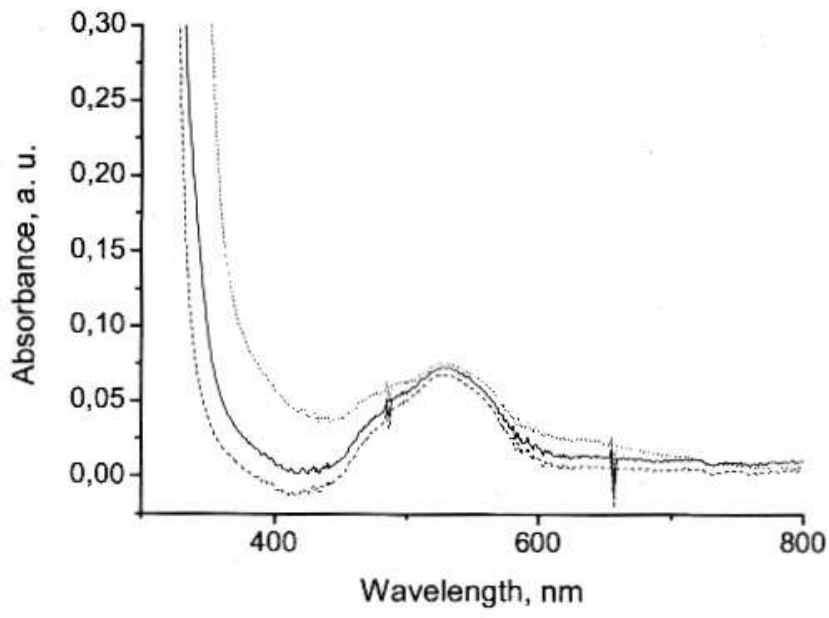

Fig. 6. Time-depending changes of UV-vis spectra of $5 \mathrm{mM}$ solution $\mathrm{Co}(\mathrm{acac})_{2}$ in $2 \mathrm{ml} \mathrm{AcOH}$ in the presence of $\mathrm{H}_{2} \mathrm{O}_{2}$ at $293 \mathrm{~K}$. The dash lines depict the initial spectrum of $\mathrm{Co}(\mathrm{acac})_{2}$, the dot line - the last spectrum taken after $2 \mathrm{\mu l} \mathrm{H}_{2} \mathrm{O}_{2}$ injection. Inset - time-traces of spectra taken at $530 \mathrm{~nm}$

The addition of hydrogen peroxide to the solution of $\mathrm{Co}^{2+}$ ions in 2-propanol that initially contains $10 \mathrm{mM}$ of quinone does not lead to the formation of oxidized form of these ions - the $\mathrm{Co}^{3+}$ absorption peak is absent (Fig. 7). The spectrum has remained unchanged during more than $1 \mathrm{~h}$ after mixing the solution with $\mathrm{H}_{2} \mathrm{O}_{2}$, which indicates the noticeable free radicals $(\mathrm{OH})$ contribution to $\mathrm{Co}^{2+}$ cations oxidation.

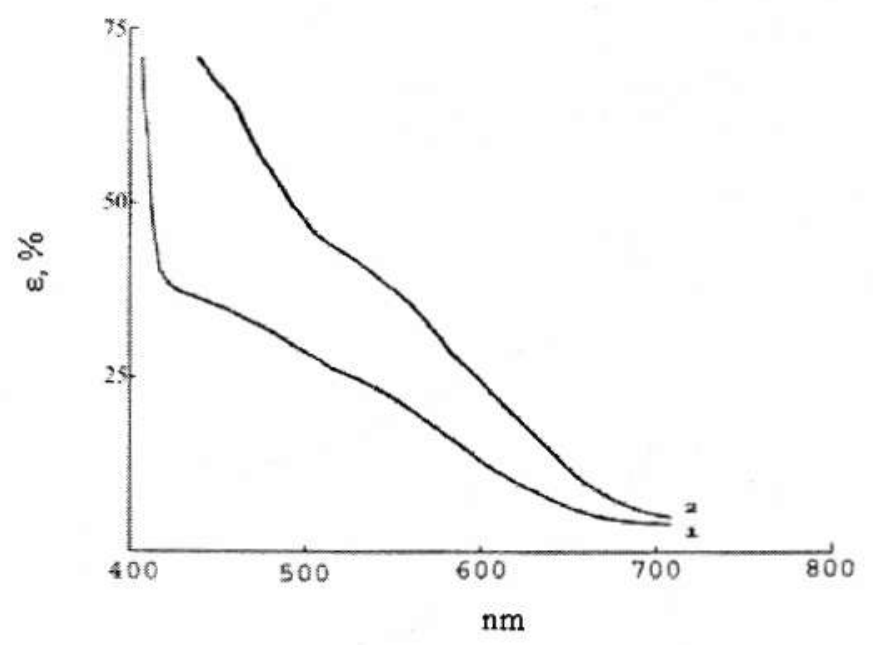

Fig. 7. Electronic absorption spectra of mixture $1 \mathrm{mM} \mathrm{Co}{ }^{2+}$ and $20 \mathrm{mM}$ quinone in $2 \mathrm{ml} i$-PrOH before (1) and after (2) of $2 \mu \mathrm{H} \mathrm{H}_{2} \mathrm{O}_{2}$ injection at $293 \mathrm{~K}$ 
It is necessary to note that according to the classic researches [15] the $\mathrm{Co}^{2+}$ with $\mathrm{H}_{2} \mathrm{O}_{2}$ reaction rate constant is by more than two orders of magnitude higher as compared to $\mathrm{Co}^{3+}$. This is explained by the low reduction ability of hydrogen peroxide. In addition to this $\mathrm{HOO}^{\circ}$ radical concentration which are also generated during $\mathrm{H}_{2} \mathrm{O}_{2}$ decomposition is so slight that the contribution of the reverse reaction of Haber-Weiss cycle $\left(\mathrm{Co}^{3+}\right.$ reduction) can be neglected.

All of the mentioned features of hydrogen peroxide catalytic decomposition in different solvents imply that there is a combinatorial effect of several physical-chemical factors that characterize the reaction medium similarly as it is observed during the peracids decomposition [16]. To pursue the study of the established dependencies in more detail further thorough researches are planned.

\section{Conclusions}

The obtained experimental data prove the critical influence of the reaction medium on the routes of $\mathrm{H}_{2} \mathrm{O}_{2}$ cleavage. The hydroxyl radicals induced route makes significant contribution into the general process of hydrogen peroxide decomposition. On the other hand the same route has a determining influence on the valent transformations of $d$-elements in the medium characterized by high specific solvation. It is necessary to note that the influence of the physical-chemical properties of the solvents on the total rate of $\mathrm{H}_{2} \mathrm{O}_{2}$ catalytic decomposition has an ambiguous and complicated character.

\section{Acknowledgements}

A part of the presented work has been done under the financial support of NATO grant CLG No. 982510. The authors (particularly O. Pokutsa) express their thanks to Prof. H.-U. Siehl (University of Ulm) for the opportunity to present the preliminary results of the research on $7^{\text {th }}$ European Symposium on Organic Reactivity (1999, Ulm, Germany).

\section{References}

[1] Hendry D. and Russel G.: J. Am. Chem. Soc., 1969, 86, 368. [2] Howard I. and Ingold K.: Canad. J. Chem., 1964, 42, 1250.
[3] Bulgakova G., Maizus Z. and Skibida I.: Kinetica i Kataliz, 1966, 7, 332.

[4] Zaikov G., Maizus Z., Emmanuel N.: Izv. Akad.Nauk SSSR, Ser. Khim., 1968, 2, 256.

[5] Emmanuel N., Zaikov G. and Maizus Z.: Rol' sredy v radikalno-tsepnykh reaktsiyakh okisleniya organicheskikh soedineniy. Nauka, Moskva 1973.

[6] Matienko L., Goldina L., Skibida I. and Maizus Z.: Izv. Akad.Nauk SSSR, Ser. Khim., 1975, $2,287$.

[7] Buchachenko A. and Sukhanova O.: Uspekhi Khimii, 1967, 36, 475 .

[8] Pocutsa A., Makitra R. and Maksim-Lutsik D.: $7^{\text {th }}$ European Symposium on Organic Reactivity, Ulm 1999, 185.

[9] Kazanskiy B. (ed.): Sintezy organicheskikh preparatov, Sbornik 1. Inostrannaya literatura, Moskva 1949.

[10] Gordon A. and Ford R.: Sputnik Khimika. Mir, Moskva 1976.

[11] Entelis S.: Zh. Vsesoyuz. Khim. Obsch. im. D. Mendeleeva, 1970, $22,324$.

[12] Denisov E. and Khudyakov I.: Chem. Rev., 1987, 87, 1313.

[13] Kuz'mina E., Shushunov V. and Schennikova M.: Uspekhi khimii organicheskikh perekisnykh soedineniy i autookisleniya. Khimiya, Moskva 1969.

[14] Barltrop J. and Coyle J.: Exited States in Organic Chemistry. John Wiley \& Sons, New York 1975.

[15] Haber F. and Weiss J.: Proc. Roy. Soc., 1934, A147, 332.

[16] Foster W. and Williams G.: J. Chem. Soc., 1962, 8, 2862.

\section{ВПЛИВ РЕАКЦІЙНОГО СЕРЕДОВИЩА НА РОЗКЛАД ПЕРОКСИДУ ВОДНЮ, КАТАЛІЗОВАНИЙ ЮНАМИ КОБАЛЬТУ}

\footnotetext{
Анотація. Розклад $\mathrm{H}_{2} \mathrm{O}_{2}$ каталізовапого кобальт (II) ацетилачетонатом, в рядігідрофільних розчинників було вивчено методом інгібіторів. Встановлено, ио фізико-хімічні властивості реакційного середовича можуть помітно впливати па ивидкість розпаду пероксиду та окислення катіону металу. Ефект середовица $є$ пропорційним його полярності та електрофільності. Наведені особливості каталітичного розкладу пероксиду водню в розчинниках вказують на присутність комбінаторного ефекту від впливу різноманітних фізико-хімічних факторів, цо характеризують реакційне середовиче.
}

Ключові слова: каталітичний розклад, пероксид водню, кобальт (II) йони, розчинники, інгібітор. 